Felicya Astwilanda Putri, M. Fachri Adnan | Upaya Pencegahan Maladministrasi Pelayanan Publik oleh Ombudsman Republik Indonesia di Provinsi Sumatera Barat

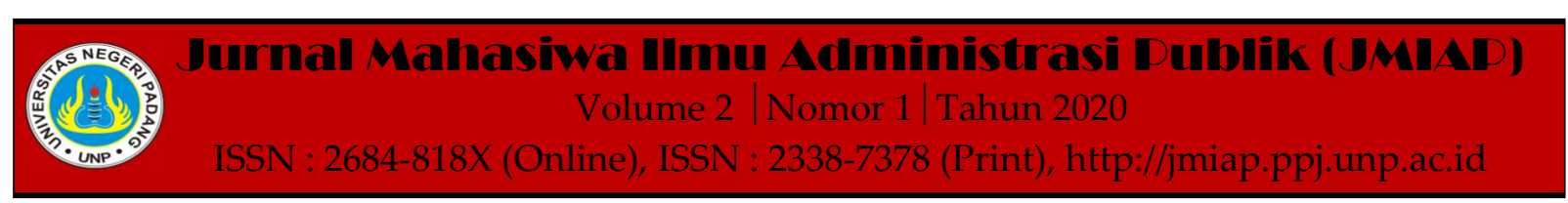

\title{
UPAYA PENCEGAHAN MALADMINISTRASI PELAYANAN PUBLIK OLEH OMBUDSMAN REPUBLIK INDONESIA DI PROVINSI SUMATERA BARAT
}

\author{
Felicya Astwilanda Putri ${ }^{1(a)}$, M. Fachri Adnan ${ }^{2(b)}$ \\ ${ }^{1}$ Jurusan Ilmu Administrasi Negara, Universitas Negeri Padang \\ ${ }^{2}$ Jurusan Ilmu Administrasi Negara, Universitas Negeri Padang \\ a)astwilanda@gmail.com, b)fachriadnan@fis.unp.ac.id
}

ABSTRACT - The maladministration happens a lot in various government agencies in Indonesia. This is evidenced by the number of maladministration reports received by various Ombudsman Representatives in Indonesia. No exception in the Province of West Sumatra, the West Sumatra Ombudsman has received 246 public reports of public administration which increased compared to 2017 with 233 reports. Substantial types that are widely discussed are the Civil Service Sector with 53 reports during 2018. The most maladministration allegations that support the most are deviations in procedure with 75 reports or 27.99\% during 2018. The purpose of this study is to review public maladministration assistance by the Ombudsman in the Province West Sumatra. This study uses interviews and investigations with research informants, namely Acting Head, Head of Prevention Assistant, Head of Report Settlement Assistant, Government Agencies as public service providers, and the public as recipients of public services. Documentation looks at the forms of maladministration public service reports, efforts to solve maladministration of public services and efforts to prevent public maladministration by the Indonesian Ombudsman Representative of West Sumatra Province. To answer the validity of source triangulation data, and data triangulation, and analyzed using qualitative techniques. From the results of the study, it appears that experiments to prevent maladministration of public services by the Ombudsman of the Republic of Indonesia Representative Province of West Sumatra have not been effective. It is proven that there are still many recipients and public service providers who do not comply with Law Number 25 of 2009 concerning public services in providing services to the public. Ombudsman to prevent maladministration properly and goals can be improved.

Keywords : Prevention, Ombudsman, Maladministration, Public Services

Corresponding author. Email.astwilanda@gmail.com,fachriadnan@fis.unp.ac.id

How to cite this article. Putri, F. Astwilanda \& Adnan, M. Fachri. (2020). Upaya Pencegahan Maladministrasi Pelayanan Publik oleh Ombudsman Republik Indonesia di Provinsi Sumatera Barat. Jurnal Mahasiwa Ilmu Administrasi Publik (JMIAP) Jurusan Ilmu Administrasi Negara Fakultas Ilmu Sosial Universitas Negeri Padang, Volume 2 (1), Hal. 33-41.

http://jmiap.ppj.unp.ac.id

ISSN : 2684-818X (Online), ISSN : 2338-7378 (Print)

Copyright $\subset$ 2020. Published by Pusat Kajian-Pemberdayaan dan Pelayanan Masyarakat (PK-P2M) FIS UNP Padang 


\section{PENDAHULUAN}

Maladministrasi telah banyak terjadi di berbagai intansi dan pemerintahan di Indonesia. Hal ini terbukti berdasarkan data yang diperoleh dari Ombudsman Republik Indonesia Perwakilan Sumatera Barat bahwa terdapat kenaikan laporan maladministrasi yang masuk selama tahun 2017-2018. Pada tahun 2017 terdapat 233 laporan maladministrasi pelayanan publik sedangkan pada tahun 2018 terdapat 246 laporan. Jenis subtansi laporan yang banyak dilaporkan yaitu pada Bidang Kepegawaian dengan 53 lapora atau 19,78\% selama tahun 2018. Dugaan maladministrasi yang paling banyak dilaporkan yaitu penyimpangan prosedur dengan 75 laporan atau 27,99\% pada tahun 2018 .

Praktek penyelenggaraan pelayanan publik yang buruk dan kaku mengakibatkan terjadinya maladministrasi dalam penyediaan pelayanan publik. Praktek pelanggaran seperti ini akan berdampak pada pengguna jasa lainnya yang kemudian juga berdampak pada kualitas pelayanan secara umum. Berbagai tuntutan masyarakat terhadap perubahan pelayanan publik yang baik memaksa pemerintah untuk mengevaluasi kualitas pelayanan publik yang ada. Hal ini karena masyarakat yang merasa kecewa akibat kurang maksimal pelayanan publik yang diterima tidak sesuai dengan Undang-Undang yang berlaku. Perilaku yang tidak wajar, kurang peduli dan tidak sopan terhadap permasalahan yang sedang dialami oleh seseorang disebabkan oleh perbuatan penyalahgunaan kekuasaan termasuk penggunaan kekuasaan semena-mena atau kekuasaan yang digunakan secara tidak wajar, intimidatif, diskriminatif, tidak adil dan tidak patut dan tidak sesuai dengan Undang-undang 25 tahun 2009 tentang Pelayanan publik maka dapat diakatakan maladministrasi.

Adnan Topan selaku Koordinator Indonesia Corruption Watch (ICW) merekomendasi pemerintah untuk membenahi sistem pelayanan publik. hal itu dapat mewujudkan pelayanan publik kepada rakyat yang bebas dari korupsi. Karena korupsi berawal dari maladministrasi pelayanan publik yang tidak sesuai dengan Undang-Undang Nomor 25 tahun 2009 Tentang pelayanan Publik. Sistem Pelayanan Publik Berpengaruh terhadap Potensi Korupsi. (Detik News Rabu 09 Januari 2019).

Sejak tahun 2012 Ombudsman berdiri di Provinsi Sumatera Barat telah menilai bahwa penyelenggaraan pelayanan publik yang dilaksanakan oleh berbagai instansi pemerintah di Sumatera Barat dinilai belum maksimal. Hal itu sesuai dengan hasil monitoring Ombudsman Perwakilan Sumatera Barat yang menjelaskan bahwa pelayanan publik oleh instansi yang ada di Provinsi Sumatera Barat belum memberikan pelayanan publik yang maksimal. Permasalahan kurangnya pelayanan publik tersebut diantaranya terdapatnya maladministrasi berupa penundaan berlarut, tidak memberikan pelayanan, penyimpangan prosedur dan tidak memberikan pelayanan.

Ombudsman RI Perwakilan Provinsi Sumatera Barat melakukan salah satu bentuk pencegahan yaitu sosialisasi, ditujukan kepada masyarakat sebagai penerima pelayanan publik dan media massa sebagai penyebarluasan fungsi dan tugas Ombudsman. Bentuk kegiatan dari sosialisasi yang telah dilakukan oleh Ombudsman RI Perwakilan Provinsi Sumatera Barat meliputi: komunikasi media, diskusi publik, sosialisasi dengan kelompok masyarakat sosialisasi di lingkungan pemerintah daerah.

Dalam kaitannya, efektivitas dapat menilai upaya pencegahan maladministrasi pelayanan publik oleh Ombudsman Republik Indonesia di Provinsi Sumatera Barat dalam memenuhi sasaran dan tujuan yang telah ditetapkan. Dikatakan efektivitas kegiatan tersebut apabila dilaksanakan dengan benar dan dapat mencapai tujuan dan memberikan hasil yang bermanfaat. 
TINJAUAN PUSTAKA

\section{Maladministrasi dalam Pelayanan Publik}

Menurut Hartono, dkk (2003) maladmoinistrasi adalah perilaku yang tidak sopan, tidak wajar dan kurang kepedulian terhadap masalah yang ada pada seseorang disebabkan oleh perbuatan penyalahgunaan kekuasaan secara semenamena dinilai sebagai kekuasaan yang digunakan untuk perbuatan yang tidak wajar, tidak adil, intimidatif atau diskriminatif, dan tidak patut didasarkan seluruhnya atau sebagian atas ketentuan undang-undang atau fakta, tidak masuk akal, atau tidak berdasarkan tindakan unreasonable, unjust, oppressive, improper, dan diskriminatif. Jadi maladministrasi adalah sesuatu perbuatan melawan hukum, yidak sesuai dan bertentangan dengan Undang-undang 25 tahun 2009 tentang pelayanan publik.

Setiap kekuasaan sekecil apapun jika untuk disalahgunakan dari administrasi negara yang memasuki semua sektor kehidupan masyarakat, maka akan menimbulkan kerugian bagi masyarakat itu sendiri, diharuskan untuk diadakan pengawasan terhadap jalannya pemerintahan, yang merupakan jaminan agar jangan sampai keadaan negara menjurus ke arah diktator tanpa batas, yang bertentangan dengan ciri negara hukum. Maladministrasi yang terjadi dapat dikatakan bahwa sebagai pintu masuk terjadinya korupsi, karena korupsi berawal dari maladministrasi yang buruk di lingkungan instansi pemerintah.

\section{Konsep Pelayanan Publik}

Istilah pelayanan berasal dari kata "layan" yang artinya menolong dalam menyediakan segala yang diperlukan oleh orang lain untuk kegiatan melayani. Pada dasarnya setiap manusia membutuhkan pelayanan, bahkan secara ekstrim dapat dikatakan bahwa pelayanan tidak dapat dipisahkan dengan kehidupan manusia (Sinambela, 2010:3).
Pada pasal 1 Undang-undang Nomor 25 tahun 2009, Pelayanan publik adalah kegiatan atau rangkaian kegiatan dalam rangka pemenuhan kebutuhan pelayanan sesuai dengan peraturan perundang-undangan bagi setiap warga negara dan penduduk atas barang, jasa, dan/atau pelayanan administratif yang disediakan oleh penyelenggara pelayanan publik.

Sementara menurut Keputusan Menteri Pendayagunaan Aparatur Negara No./KEP/25//M.PAN/2/2004 Pelayanan publik adalah segala kegiatan pelaksanaan yang dilaksanakan oleh penyelenggara pelayanan publik sebagai upaya pemenuhan kebutuhan pelayanan, maupun dalam rangka pelaksanaan ketentuan peraturan perundang-undangan.

Pada Pasal 5 UU No 25 Tahun 2009 Ruang lingkup pelayanan publik menurut Undang-Undang Pelayanan Publik meliputi pelayanan barang publik dan jasa publik serta pelayanan administratif yang diatur dalam peraturan perundangundangan. Dalam ruang lingkup tersebut, termasuk pendidikan, pengajaran, pekerjaan dan usaha, tempat tinggal, komunikasi dan informasi, lingkungan hidup, kesehatan, jaminan sosial, energi, perbankan, perhubungan, sumber daya alam, pariwisata, dan sektor lainnya.

\section{Upaya Pencegahan Maladministrasi Pelayanan Publik}

Ombudsman Republik Indonesia Perwakilan Provinsi Sumatera Barat telah melakukan beberapa upaya Pencegahan Maladministrasi Pelayanan publik sejak berdirinya Ombudsman Perwakilan di Provinsi Sumatera Barat. Berbagai upaya berbentuk kegiatan-kegiatan telah dilakukan agar maladministrasi pelayanan publik di provinsi Sumatera Barat dapat dicegah agar tidak terjadi. Terdapat 2 bentuk upaya pencegahan maladministrasi pelayanan publik yang telah dilakukan oleh Ombudsman Sumbar. Bentuk upaya pencegahan pertama yaitu pre-emtif, bentuk upaya pencegahan ini dilakukan untuk 
menanamkan nilai dan norma kepada penerima layanan publik agar paham dan maladministrasi dapat dihindari. Sasaran dari upaya pencegahan maladministrasi pelayanan publik bentuk pre-emtif yang dilakukan oleh Ombudsman yaitu masyarakat sebagai penerima pelayanan publik. Bentuk upaya pencegahan maladministrasi pelayanan publik yang kedua yaitu preventif, upaya pencegahan ini dilakukan agar pemberi layanan publik paham dan dapat memberikan pelayanan sesuai dengan Undang-undang yang berlaku agar tidak terjadi maladministrasi. Sasaran dari bentuk upaya pencegahan maladministrasi ini yaitu instansi pemerintahan sebagai pemberi layanan publik kepada masyarakat.

\section{Efektifitas Pencegahan Maladministrasi Pelayanan Publik}

Efektivitas berasal dari kata efektif dari bahasainggris effective yang artinya berhasil. Efektif dalam Kamus Besar Bahasa Indonesia berarti dapat membawa hasil, berhasil guna. Menurut Robbins dalam Moh. Pabundu Tika (2010:129) mendefinisikan efektivitas sebagai tingkat pencapaian organisasi jangka pendek dan jangka panjang. Dengan kata lain efektivitas merupakan unsur pokok untuk mencapai tujuan atau sasaran yang telah ditentukan dalam setiap organisasi, kegiatan atau program.

Ukuran efektivitas menurut Duncan yang dikutip Richard M. Steers (1985:53) dalam Jurnal Reza Silvianis, mengatakan mengenai ukuran efektivitas, sebagai berikut:

a) Pencapaian Tujuan adalah keseluruhan upaya pencapaian tujuan harus dipandang sebagai suatu proses. Oleh karena itu, agar pencapaian tujuan akhir semakin terjamin, diperlukan pentahapan, baik dalam arti pentahapan pencapaian bagian-bagiannya maupun pentahapan dalam arti periodisasinya. Pencapaian tujuan terdiri dari beberapa faktor, yaitu: Kurun waktu dan sasaran yang merupakan target kongktit. b) Integrasi yaitu pengukuran terhadap tingkat kemampuan suatu organisasi untuk mengadakan sosialisasi, pengembangan konsensus dan komunikasi dengan berbagai macam organisasi lainnya. Integrasi menyangkut proses sosialisasi.

c) Adaptasi adalah kemampuan organisasi untuk menyesuaikan diri dengan lingkungannya. Untuk itu digunakan tolak ukur proses pengadaan dan pengisian tenaga kerja.

\section{METODE PENELITIAN}

Penelitian ini bersifat deskriptif dengan pendekatan kualitatif, yaitu peneliti mencoba untuk menggambarkan dan mengungkapkan semua fenomena dari bentuk-bentuk maladministrasi pelayanan publik, upaya pencegahan yang dilakukan, dan efektifitas upaya pencegahan yang telah dilakukan oleh ombudsman. Penelitian ini dilakukan di Ombudsman Republik Indonesia Perwakilan Provinsi Sumatera Barat. Informan dari penelitian ini yaitu yaitu Pelaksana Tugas Kepala, Kepala keasistenan Bidang Pencegahan, Kepala keasistenan Bidang Penyelesaian Laporan, Instansi Pemerintah sebagai penyedia layanan publik dan masyarakat sebagai penerima layanan publik.

Data yang digunakan yaitu data primer dan data sekunder, yang berasal dari wawancara dan studi dokumentasi. Untuk menguji validitas data digunakan triangulasi sumber, triangulasi data, dan dianalisis menggunakan teknik kualitatif mulai dari reduksi data, penyajian data, hingga penarikan kesimpulan. Penelitian ini bertujuan memberikan gambaran secara jelas, lengkap, dan teliti dengan cara mengumpulkan, menyusun, mengklarifikasikannya, menganalisa serta menginterpretasikan data yang didapat untuk memecahkan masalah mengenai upaya pencegahan maladministrasi pelayanan publik oleh Ombudsman RI Perwakilan Provinsi Sumatera Barat. 
HASIL DAN PEMBAHASAN

\section{Upaya Pencegahan Maladministrasi Pelayanan Publik Oleh Ombudsman Republik Indonesia di Provinsi Sumatera Barat}

Efektivitas akan selalu berkaitan antara hasil yang diharapkan dengan hasil yang sesungguhnya dicapai. Pada upaya pencegahan maladministrasi pelayanan publik perlu dilihat bagaimana tingkat efektivitasnya agar tujuan dari upaya pencegahan maladministrasi pelayananan publik dapat tercapai. Efektivitas upaya pencegahan maladministrasi pelayanan publik melihat seberapa efektif upaya pencegahan maladministrasi pelayanan publik yang dilakukan oleh Ombudsman RI Perwakilan Provinsi Sumatera Barat dalam melakukan tugas dan wewenangnya sesuai dengan Undang-Undang 37 tahun 2008 tentang Ombudsman Republik Indonesia.

Analisa efektivitas upaya Ombudsman Republik Indonesia dalam pencegahan maladministrasi pelayanan publik dilihat menggunakan teori efektivitas Duncan yang dikutip Richard M. Steers dalam (1985:53) yang mengukur tingkat keefektifan dengan indikator (a) Adaptasi , (b) Integrasi, (c) Pencapaian tujuan.

\section{1) Adaptasi}

Menurut Robbins (2003), adaptasi adalah suatu proses yang menempatkan manusia yang berupaya mencapai tujuantujuan atau kebutuhan untuk menghadapi lingkungan dan kondisi sosial yang berubah-ubah agar tetap bertahan.

Dalam pengukuran efektivitas, adaptasi menilai seberapa jauh suatu organisasi berhasil dalam menyesuaikan diri dengan lingkungannya. Hal ini juga berarti bahwa bagaimana Ombudsman Republik Indonesia Perwakilan Provinsi Sumatera barat dapat menyesuaikan lembaganya dengan sasaran pecegahan dan organisasi lain dalam hal melakukan upaya pencegahan maladministrasi pelayanan publik.

Berdasarkan temuan peneliti dapat dilihat bahwa Ombudsman Republik
Indonesia Perwakilan Provinsi Sumatera Barat dalam upaya pencegahan maladministrasi pelayanan publik, belum dapat beradaptasi dengan baik. Hal ini dinilai dari beberapa tanggapan yang diberikan oleh penyelenggara dan penerima pelayanan publik. Bagi penyelenggara pelayanan publik, beberapa instansi belum memiliki pandangan yang baik terhadap Ombudsman.

Berdasarkan hasil wawancara peneliti dengan Dinas Perdagangan Kota Padang yaitu instansi terkait menganggap bahwa jika telah dipanggil atau berurusan dengan Ombudsman maka akan di Cap sebagai penyelenggara pelayanan publik yang bermasalah dan diduga melakukan maladministrasi. Selain itu hasil wawancara dengan Dinas Penanaman Modal Pelayanan Terpadu Satu Pintu (DPMPTSP) yaitu Dinas terkait mengatakan bahwa Ombudsman Sumatera Barat belum mampu masuk ke dalam lapisan instansi-instansi yang menjadi wewenang pengawasan Ombudman dengan baik. Hal ini karena pihak terkait merasa adanya suatu kecemasan dan kekhawatiran jika telah dipanggil oleh Ombudsman. Ombudsman dianggap menjadi suatu lembaga yang menakutkan bagi para Instansi penyelenggara pelayanan publik karena belum mampu beradaptasi dengan baik memberitahu apa tujuan Ombudsman hadir sebagai lembaga pengawas pelayanan publik.

Masyarakat sebagai penerima pelayanan publik dinilai juga belum memiliki pandangan yang baik terhadap Ombudsman Sumatera Barat. Dilihat dari laporan maladministrasi pelayanan publik yang meningkat masuk ke Kantor Ombudsman Sumatera Barat, masyarakat dinilai sangat mempercayakan laporannya akan ditangani oleh Ombudsman. Berdasarkan hasil wawancara yang dilakukan peneliti masyarakat sangat berharap Ombudsman akan menyelesaikan laporan mereka, tetapi disisi lain bagi masyarakat yang laporannya tidak dapat ditangani oleh ombudsman karena laporan tersebut bukan menjadi 
kewenangan Ombudsman merasa kecewa. Masyarakat belum begitu mengerti akan apa saja yang menjadi kewenangan Ombudsman. Ketika terjadi maladministrasi masyarakat langsung melapor ke Ombudsman tanpa mengetahui laporannya menjadi kewenangan apa tidak. Hal ini dinilai bahwa Ombudsman Sumatera Barat belum optimal dalam beradaptasi kepada masyarakat untuk memperkenalkan fungsi tujuan dan kewenangan Ombudsman.

\section{2) Integrasi}

Menurut Duncan yang Dikutip Richard M. Steers (1985:53) Integrasi yaitu pengukuran terhadap tingkat kemampuan suatu organisasi untuk mengadakan sosialisasi, pengembangan konsesus dan komunikasi dengan berbagai macam organisasi lainnya. Integrasi menyangkut proses sosialisasi, Integrasi dapat dikatakan sebagai proses yang menyangkut tentang hubungan suatu organisasi tertentu dengan lingkungan yang ada di sekitarnya. Integritas merupakan pengukuran yang dilakukan terhadap tingkat kemampuan yang dimiliki oleh suatu organisasi untuk mengadakan sosialisasi dengan berbagai macam organisasi lainnya. Sosialisasi merupakan hal yang utama dalam pelaksanaan dan pengembangan suatu organisasi, sehingga dengan adanya sosialisasi yang baik akan memancing timbulnya komunikasi yang baik pula.

Berdasarkan hasil temuan peneliti Persepsi dan ekspektasi masyarakat terhadap Ombudsman RI berbanding terbalik dengan kenyataannya. Masyarakat masih banyak yang tidak mengetahui keberadaan lembaga Ombudsman, masih berprasangka bahwa Ombudsman RI sebagai lembaga swadaya masyarakat, Ombudsman RI sebagai Organisasi Perangkat Dinas (OPD), dan atau Ombudsman RI dibawah kementerian. Berdasarkan hasil wawancara peneliti dengan beberapa penerima layanan publik yaitu masyarakat di beberapa daerah di Sumatera Barat menunjukan bahwa
Ombudsman Republik Indonesia Perwakilan Provinsi Sumatera Barat belum dikenal dan tidak diketahui keberadaannya. Hal ini dinilai Ombudsman Republik Indonesia Perwakilan Provinsi Sumatera Barat dalam melakukan sosialisasi pengenalan fungsi,tugas dan wewenangnya kepada masyarakat belum berhasil.

Bagi penyelenggara pelayanan publik juga belum banyak yang mengetahui lembaga Ombudsman. Hal ini ditandai dari hasil wawancara dengan beberapa instansi pemerintah yang belum begitu paham akan potensi maladministrasi yang dapat terjadi. Instansi terkait juga tidak tahu bahwa setiap kegiatan penyelenggaraan pelayanan publik telah diawasi oleh lembaga Ombudsman.

Penelitian terdahulu juga dilakukan oleh Muh. Zafri Ramadhoan dalam tulisannya yang dimuat dalam portal patriot.id dengan judul "Ombudsman RI antara Dikenal dan Tidak Dikenal", menyampaikan hasil survei kecil-kecilan dikampusnya, adapun hasilnya yaitu dari 10 orang mahasiswa dan hasilnya sangat mengecewakan bahwa $90 \%$ mahasiswa tidak mengetahui apa itu Ombudsman khususnya di NTB. Padahal Ombudsman merupakan lembaga yang sangat dibutuhkan oleh masyarakat, yang memiliki tugas menerima laporan dari masyarakat atas dugaan maladministrasi. Zafri Ramadhon pada penutupan tulisannya, berharap Ombudsman sebagai lembaga negara di Indonesia, diketahui keberadaannya di mayarakat. Menurutnya penguatan melalui Undang-Undang No.37 tahun 2008 tentang Ombudsman Republik Indonesia dapat mencapai tujuan sesuai asas kepastian, keadilan dan kemanfatan. Pada akhirnya publik atau masyarakat mengetahui bahwa ada lembaga negara yang bertugas dan berfungsi dalam pengawasan pelayanan publik di Indonesia.

Kurang dikenalnya Ombudsman RI oleh masyarakat dapat dikatakan tidak berjalannya fungsi,tugas dan wewenang Ombudsman RI secara menyeluruh. Berdasarkan Undang-Undang Nomor 37 tahun 2008 tentang Ombudsman Republik Indonesia, Ombudsman berwenang 
menyampaikan saran kepada Presiden, kepala daerah, atau pimpinan penyelenggara negara lainnya guna perbaikan dan penyempurnaan organisasi dan/atau prosedur pelayanan publik. Ombudsman juga berwenang menyampaikan saran kepada Dewan Perwakilan Rakyat dan/atau Presiden, Dewan Perwakilan Rakyat Daerah dan/atau kepala daerah agar terhadap undang-undang dan peraturan perundang-undangan lainnya diadakan perubahan dalam rangka mencegah Maladministrasi.

Namun kedua kewenangan tersebut belum dapat diukur sejauh apa keberhasilannya dalam perbaikan pelayanan publik di Indonesia. Lemahnya sosialisasi Ombudsman RI kepada masyarakat juga sama terhadap terlapor (penyelenggara pelayanan publik), seringkali terlapor tidak patuh dalam menindaklanjuti rekomendasi Ombudsman RI. Para penyelenggara pelayanan publik, belum mengenal lebih dalam Ombudsman RI baik dari fungsi, tugas dan wewenang. Mereka lebih menakuti atasan langsung (waskat) atau media sosial (facebook, instagram, twitter dan youtube) yang menjadi faktor eksternal kekinian, atau diberitakan oleh media cetak. Tantangan tersebut menjadi pekerjaan rumah bagi Ombudsman RI, maka dibutuhkan solusi yang taktis dan berwibawa.

\section{3) Pencapaian Tujuan}

Menurut Duncan dalam Richard M. Steers (1985:53) Pencapaian tujuan adalah keseluruhan upaya pencapaian tujuan harus dipandang sebagai suatu proses. Oleh karena itu tujuan akhir semakin terjamin, diperlukan pentahapan, baik dalam arti pentahapan pencapaian bagian-bagiannya maupun pentahapan dalam arti periodisasinya. Dalam pengukuran efektivitas, optimalisasi tujuan menilai seberapa jauh suatu organisasi berhasil dalam mencapai tujuan-tujuan yang telah ditetapkan. Keseluruhan strategi dalam upaya pencapaian tujuan merupakan suatu proses yang harus diperhatikan.
Setiap tahapan strategi yang dilakukan akan menentukan keberhasilan dalam pencapaian tujuan.

Berdasarkan hasil temuan peneliti, dilihat dari perencanaan upaya pencegahan yaitu suatu proses untuk menentukan tindakan masa depan yang tepat dengan memperhatikan sumberdaya yang tersedia. Upaya pencegahan maladministrasi pelayanan publik oleh Ombudsman Sumatera Barat dilakukan oleh 8 orang Asisten Ombudsman. Berdasarkan hasil wawancara secara kualitas dapat dinilai bahwa sumberdaya Ombudsman Sumatera Barat dinilai baik, karena sumberdaya Ombudsman telah memahami dan sadar akan tugas,fungsi dan wewenang sesuai dengan Undang-Undang Nomor 37 tahun 2008 tentang Ombudsman Republik Indonesia. Namun secara kuantitas, sumberdaya manusia pada Ombudsman Sumatera Barat dinilai tidak mencukupi karena wilayah kerja dalam penyelesaian laporan dan Upaya pencegahan meliputi 19 Kabupaten dan Kota di Sumatera Barat. Sedangkan sumberdaya manusia yang ada hanya 8 orang dengan beban kerja dan tanggung jawab yang banyak.

Pada indikator pembagian tugas pelaksanaan upaya pencegahan maladministrasi pelayanan publik dilakukan oleh 8 orang sumberdaya manusia. Ombudsman Sumatera Barat mempunyai dua tugas pokok yaitu yang paling utama adalah penyelesaian laporan dan tugas kedua adalah upaya pencegahan. Dalam praktiknya upaya pencegahan maladministrasi kurang optimal dilakukan karena sumberdaya Ombudsman lebih fokus kepada penyelesaian laporan sebagai tugas pokok Ombudsman disamping upaya pencegahan.

Indikator pelaksanaan diukur dari pencapaian target dari perencanaan upaya pencegahan yang telah dilakukan. Upaya pencegahan maladministrasi pelayanan publik dinilai belum mencapai keefektivitasan karena tujuan dari upaya pencegahan dalam mengurangi angka terjadinya maladministrasi belum tercapai. 
Pada tahun 2018 terdapat 246 laporan maladministrasi pelayanan publik yang meningkat dibanding tahun 2017 dengan 233 laporan. Dapat disimpulkan bahwa maladministrasi pelayanan publik masih terjadi pada tahun 2018 dan tujuan dari upaya pencegahan maladministrasi belum tercapai.

\section{PENUTUP}

Berdasarkan hasil penelitian dan pembahasan yang telah dilakukan oleh peneliti maka dapat disimpulkan bahwa:

Pertama, bentuk-bentuk laporan maladministrasi pelayanan publik yang diterima oleh Ombudsman RI Perwakilan Provinsi Sumatera Barat terdapat kenaikan jumlah laporan masyarakat yang masuk ke Ombudsman RI Sumbar dari tahun 2017 ke tahun 2018. Pada tahun 2017 terdapat 233 laporan masyarakat yang masuk ke Ombudsman Sumbar. Sedangkan tahun 2018 terdapat kenaikan yaitu 246 laporan masyarakat yang masuk ke Ombudsman Sumbar. Dari meningkatnya laporan masyarakat di tahun 2018, menggambarkan mulai meningkatnya kesadaran masyarakat yang berani melaporkan dugaan maladministrasi bahwa pada sektor-sektor pelayanan publik masih banyak yang bermasalah.

Kedua, upaya pencegahan maladministrasi pelayanan publik yang telah dilakukan oleh Ombudsman Republik Indonesia Perwakilan Provinsi Sumatera Barat telah melakukan upaya Pencegahan Maladministrasi sejak berdirinya Ombudsman Perwakilan di Provinsi Sumatera Barat. Berbagai upaya berbentuk kegiatan-kegiatan telah dilakukan agar maladministrasi pelayanan publik di provinsi Sumatera Barat dapat dicegah agar tidak terjadi. Terdapat dua bentuk upaya pencegahan maladministrasi pelayanan publik yang telah dilakukan oleh Ombudsman Sumbar. Bentuk upaya pencegahan pertama yaitu pre-emtif, bentuk upaya pencegahan ini dilakukan untuk menanamkan nilai dan norma kepada penerima layanan publik agar paham dan maladministrasi dapat dihindari. Sasaran dari upaya pencegahan maladministrasi pelayanan publik bentuk pre-emtif yang dilakukan oleh Ombudsman yaitu masyarakat sebagai penerima pelayanan publik. Bentuk upaya pencegahan maladministrasi pelayanan publik yang kedua yaitu preventif, upaya pencegahan ini dilakukan agar pemberi layanan publik paham dan dapat memberikan pelayanan sesuai dengan Undang-undang yang berlaku agar tidak terjadi maladministrasi. Sasaran dari bentuk upaya pencegahan maladministrasi ini yaitu instansi pemerintahan sebagai pemberi layanan publik kepada masyarakat.

Ketiga, efektivitas upaya pencegahan maladministrasi pelayanan publik yang telah dilakukan oleh Ombudsman RI Perwakilan Provinsi Sumatera Barat dapat dikatakan belum berjalan dengan efektif. Hal ini terbukti karena masih banyaknya penerima dan pemberi layanan publik yang belum mengetahui lembaga Ombudsman sebagai lembaga pengawas pelayanan publik. Adanya para penyelenggara pelayanan publik yang tidak sesuai dengan Undang-undang Nomor 25 tahun 2009 tentang pelayanan publik dalam memberikan pelayanan kepada masyarakat. Proses upaya pencegahan maladministrasi pelayanan publik tidak berjalan dengan optimal karena kurangnya sumberdaya manusia yang ada pada Ombudsman Sumbar. Ombudsman RI Sumbar hanya memiliki 8 orang asisten yang menangani penyelesaian laporan dan upaya pencegahan, sedangkan wilayah kerja tanggung jawabnya mencakup 19 Kabupaten dan Kota di provinsi Sumatera Barat.

\section{DAFTAR KEPUSTAKAAN}

Abdul Haliq. 2017. Analisis Kasus Mal Administrasi Di Ombudsman RI Perwakilan Kalimantan Selatan Tahun 2013-2015: As Siyasah, Vol. 2, No. 1. 
Afriva Khaidir, PhD. Ears of the People: Kajian terhadap Integritas dalam Administrasi Publik dalam Mekanisme Pelaporan pada Ombudsman Sumatera Barat: hal 1-8.

Asmara, Galang. 2005. Ombudsman Nasional dalam Sistem Pemerintahan Negara Republik Indonesia. Yogyakarta: Laksbang Pressindo.

Ayu Desiana, S.H., M.H. Analisis Konsep Pengawasan Ombudsman Terhadap Penyelenggaraan Pelayanan Publik: Jurnal Hukum hal 172-192.

Hartono, Sunaryati dkk. 2003. Panduan Investigasi Untuk Ombudsman Indonesia.Jakarta: Komisi Ombudsman Nasional.

Kelani Putri. 2017. Efektivitas Kinerja Ombudsman Dalam Menangani Pengaduan Pelayanan (Kasus Maladministrasi Di Kota Pekanbaru): JOM FISIP Vol. 4 No. 1.

Lexy J. Moeloeng. 2005. Metode Penelitian Kualitatif, Bandung: PT Remaja Rosdakarya.

Nora Eka Putri. 2014. Efektivitas penerapan jaminan kesehatan nasional melalui bpjs dalam pelayanan kesehatan masyarakat miskin di kota padang.Jurnal fisip Vol. 10, No. 2. (Diakses 24 maret 2019, pukul 02.39 WIB).

Ombudsman Indonesia (masa lalu, sekarang dan mendatang) 2009. Komisis Ombudsman Nasional. Jakarta.

Peraturan Ombudsman Republik Indonesia Nomor 26 Tahun 2017 Tentang Tata Cara Penerimaan, Pemeriksaan, dan Penyelesaian Laporan.

Peraturan Pemerintah Republik Indonesia No.21 Tahun 2011 Tentang
Pembentukan, Susunan, dan Tata Kerja Perwakilan Ombudsman Republik Indonesia di Daerah.

Richard M.Steers. 1985. Efektifitas Organisasi. Jakarta : Erlangga.

Sugiyono, 2002. Metode Penelitian Kualitatif dan $R \& D$. Bandung: Alfabeta.

Undang-Undang Dasar Negara Republik Indonesia Tahun 1945.

Undang-Undang Negara Republik Indonesia Nomor 25 Tahun 2009 tentang Pelayanan Publik.

Undang-Undang Negara Republik Indonesia Nomor 37 tahun 2008 tentang Ombudsman Republik Indonesia. 